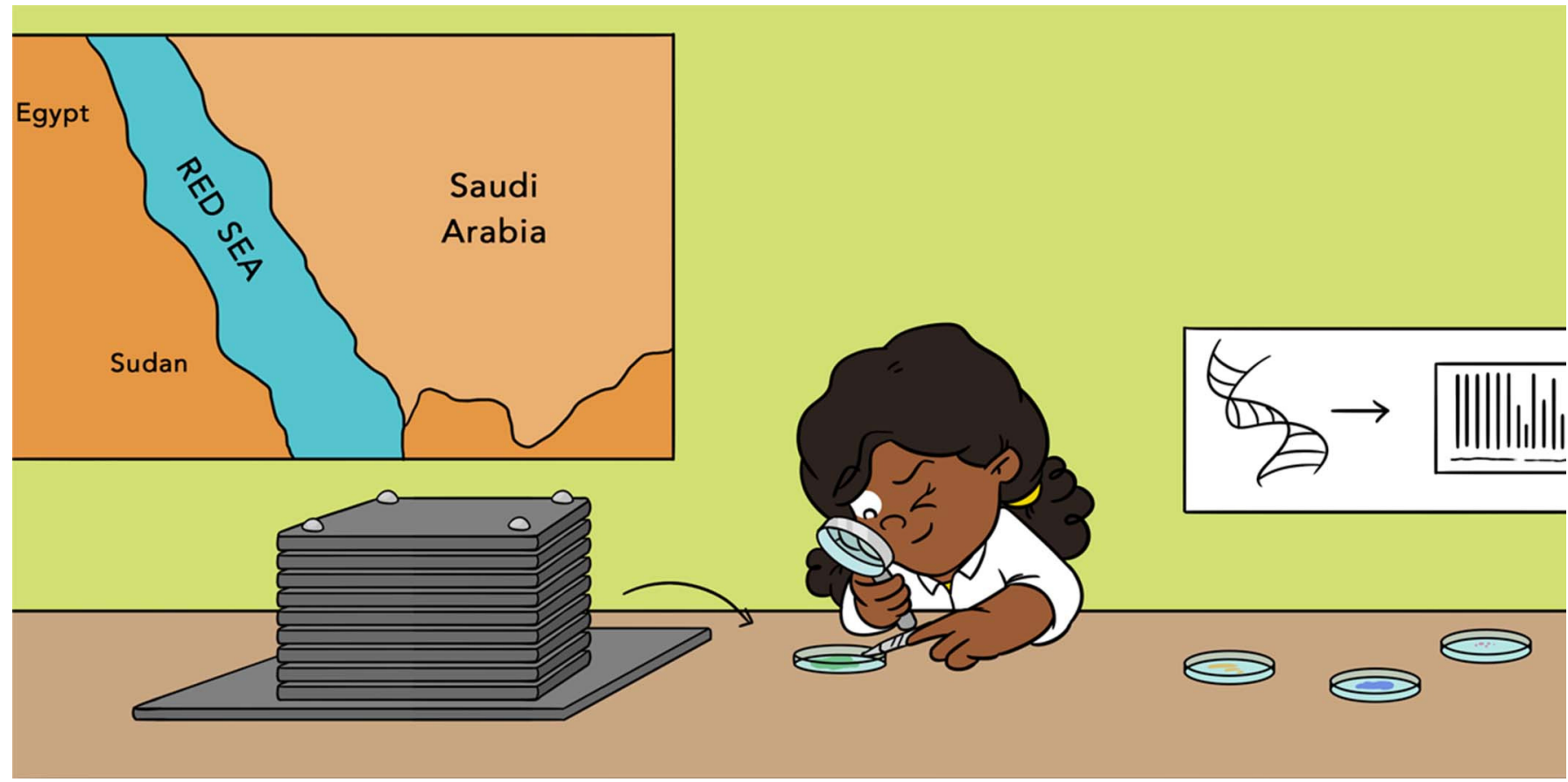

\title{
TREASURE REEF: REVEALING THE HIDDEN CREATURES OF CORAL REEFS
}

\section{Jennifer Otoadese and Susana Carvalho *}

Biological and Environmental Sciences and Engineering, Red Sea Research Center, King Abdullah University of Science and Technology, Thuwal, Saudi Arabia

\section{YOUNG REVIEWERS:}

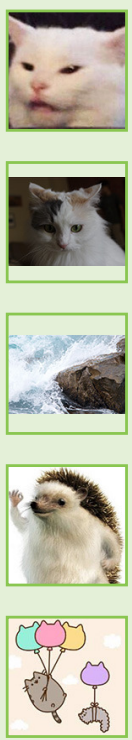

BJORN

AGE: 15

HAZEM

AGE: 14

REBECCA

AGE: 15

SAMUEL

AGE: 14

XENIA

AGE: 15
Under the oceans, scientists estimate that there are hundreds of thousands of sea creatures yet to be discovered. These hidden animals can be found in the open ocean, in deep trenches at the bottom of the sea, and in coral reefs. In tropical coral reefs, hidden animals include tiny fish, crabs, octopuses, sea snails, starfish, slugs, and other mysterious animals that are hard to see. These mysterious animals can help us better understand how coral reefs function. But how can we study what we cannot find? Scientists working along the east coast of the Red Sea in Saudi Arabia are using two new methods to bring these hidden creatures from the reef to the laboratory. Like detectives, these researchers are finding, describing, and learning about the roles these tiny animals play in keeping coral reefs healthy. We protect what we know, so the race is on to find and preserve the Red Sea's biodiversity. 


\section{BIODIVERSITY}

The variability between the characteristics of different living things. This includes diversity within species (different sizes, colors, genetics, etc.), between species, and diversity of habitats (for example, deserts, forests, lakes, coastal areas, mountains).

\section{ECOSYSTEMS}

A dynamic area of plants, animals, microorganisms, and their non-living environment interacting together.

\section{AN UNDERWATER MYSTERY}

What if we could figure out how to protect our oceans so that life underwater thrives? Or, what if we find a marine area that has been damaged, and we could bring back the original fish and the web of life that the fish depend on? Establishing what is called no-take marine protected areas may be just the answer to these questions. No-take marine protected areas prevent any human activity, such as fishing, mining, or oil drilling, from taking place, allowing the marine life to thrive without interference by people. But establishing these protected areas is tricky. To know what to protect, we have to identify all the organisms in that area. We also need to understand the level of biodiversity and connection between ecosystems that is necessary for the larger marine environment to thrive.

And here lies the mystery: how can we protect what lies beneath the surface of our seas if we barely know what is there? According to scientists, more than $80 \%$ of the oceans are unmapped and unexplored [1]. The race is on to find and identify marine species, because knowing about the world's marine species is important for protecting our oceans. Extinctions from habitat loss and climate change are progressing at alarming rates. Around $20 \%$ of marine species are at risk of extinction and we urgently need to document what is happening in order to better understand why and to learn how to prevent it.

Scientists at the Red Sea Research Center in Saudi Arabia are using two scientific research tools to study the smaller life in the Red Sea reefs. If we unlock the mysteries of life in coral reefs, we may be better able to design marine protected areas that flourish for you and for future generations to treasure.

\section{WHAT LIES BENEATH?}

Underwater, coral reefs can offer spectacular beauty with their colorful corals, fish, sponges, giant clams, and turtles. Coral reefs are like the rainforests of the seas. They provide people with countless goods and services, including food, shoreline protection, sacred spaces, and regulation of processes on earth that make our planet habitable.

For other species, coral reefs are life-giving. In the movie "Finding Nemo," Nemo lived in a sea anemone, in the shelter of a coral reef. Reefs are important nurseries for young fish and help to provide protection from predators and nutrients (food) for growth. But if you look even closer at life in the reef, you can find equally astounding creatures the size of your fingernail and even smaller. Creatures like tiny crabs, octopuses, worms, snails, starfish, and fishes (Figure 1) exist there. Because of their size, these creatures are hard to find using traditional marine surveys, which only capture what the eye can see. These traditional methods include using divers to take photos of easy-to-see organisms and looking at pictures taken from space using 
Figure 1

Examples of animals living on coral reefs collected using ARMS in the Red Sea. From left to right, on the upper row: a crab, an octopus and a worm; on the lower row: a sea snail, a starfish and a fish. Photo credits John K. Pearman.

\section{SENTINEL SPECIES}

An important species in an ecosystem that can tell scientists about the health of that ecosystem. Loss of a sentinel species can provide advance warning that an ecosystem is in danger.

ARMS

Autonomous reef monitoring structures are made of multiple plates placed on top of each other, mimicking the 3D structure of reefs. ARMS enable the study of hidden organisms that because of their small size or because they mainly come out at night, are often unseen using visual reef surveys by divers.

\section{DNA}

Long strands of chemicals that contain the genes-or blueprints-of an organism. The genes in an organism's DNA contain the information that helps to determine its shape, size, and behavior.

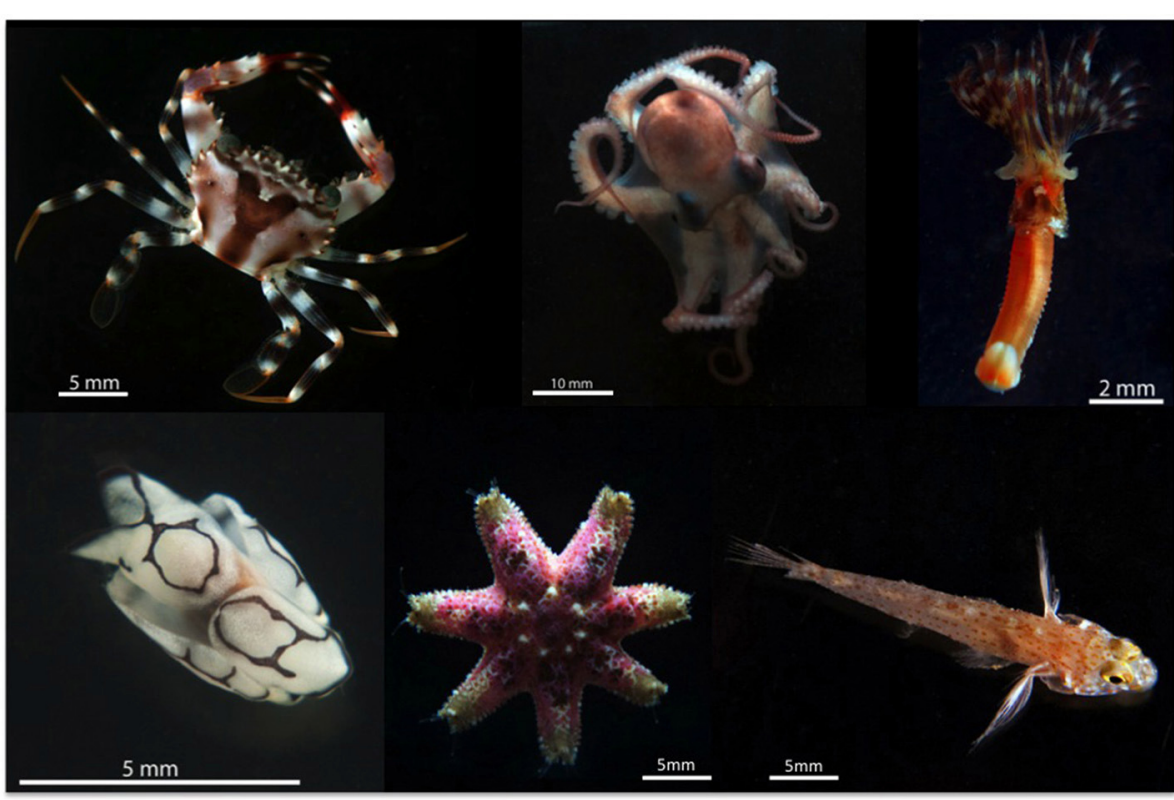

Figure 1

satellites. To get the full picture of biodiversity, we need to go smaller, because these micro-creatures, some of which hide or only come out at night, are estimated to make up $70 \%$ of coral reefs.

These hidden creatures represent most of the reef biodiversity, but if we do not look at them, how can we know if we are losing species because of climate change or pollution, or gaining species that were not there before? These changes to coral reefs can threaten the health of the marine environment.

With information about the smallest forms of marine life we can:

1) Find similarities and differences-between reefs, between near-shore and off-shore environments, between seas, and across all the oceans on Earth;

2) Investigate if there are key species, called sentinel species, that help scientists to figure out if an ecosystem is healthy or degraded; and

3) Establish early warning systems. If there are sentinel species that we know should be present for a healthy system, and we discover these creatures are missing, we can warn governments and marine managers that they must take action to protect that marine environment. Some of these actions may include controlling discharges of sewage, improving water treatment, or even limiting fishing activities.

Two techniques have recently been combined to find the creatures living out of plain sight. They are called autonomous reef monitoring structures (ARMS) and DNA barcoding. 
Figure 2

(A) Drawing of an autonomous reef monitoring structure (ARMS), showing the dimensions and the main components: (i) nine strong plastic plates with spaces for animals to settle and hide; (ii) a base; (iii) weights to allow for stability against waves and currents. (B) One ARMS unit sitting on a Red Sea coral reef. (C) Examples of creatures $>2 \mathrm{~mm}$ in size that have been collected in the Red Sea using ARMS. (D) One ARMS plate after 2 years under water, showing some organisms that settled and grew there. Photo credits Joao Curdia (A), Jessica Bouwmeester (B), and John K. Pearman $(C, D)$

\section{TAXONOMY}

The science of classifying living things into groups called. among others, families or species that share common characteristics.
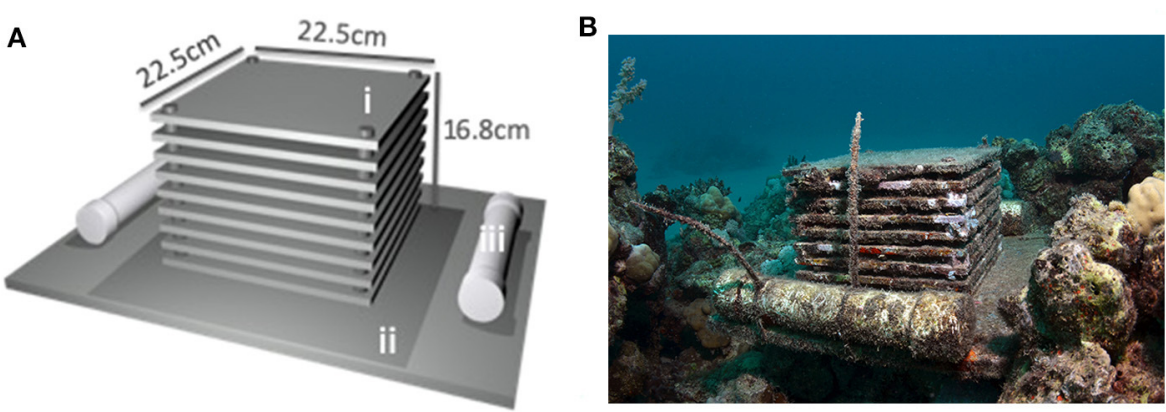

C

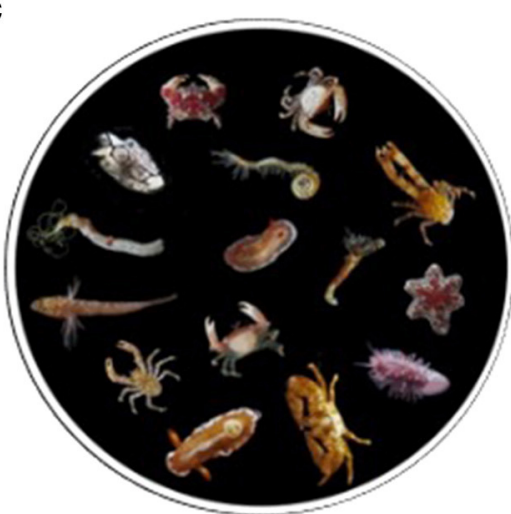

D

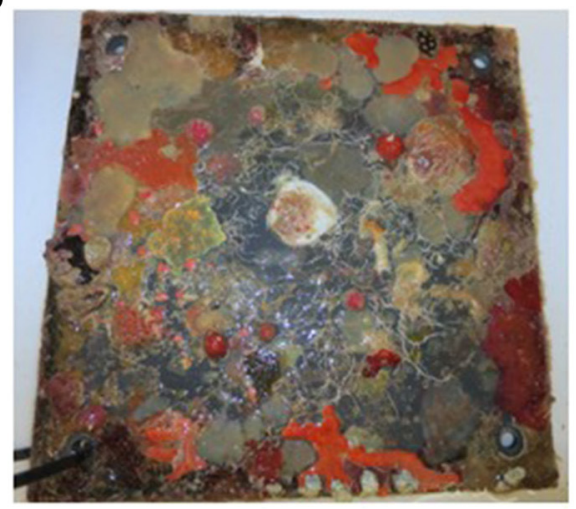

Figure 2

\section{A TALE OF TWO TECHNIQUES: FROM THE OCEAN TO THE LABORATORY}

\section{What Are Autonomous Reef Monitoring Structures (ARMS)?}

ARMS are sets of nine plates placed on top of each other, with spaces in between to allow for creatures to crawl inside and water to flow through (Figures 2A,B). The design of these ARMS mimics the 3D nature of a coral reef, with some parts exposed to light, other areas with limited light, and some areas that allow animals to find refuge from predators. ARMS are first made in a workshop before a scientific diver takes them underwater and places them on the bottom of a reef. After 1-3 years, the diver returns to collect the ARMS from the site. The ARMS will then be covered in marine growth, including animals, plants, algae, and bacteria. Marine scientists carefully photograph all the life they find on the ARMS (Figure 2D). Where possible, the largest creatures ( $>2 \mathrm{~mm}$; Figure $2 \mathrm{C}$ ) uncovered on each ARMS is identified by scientists called taxonomists, whose job it is to classify animals to a particular family or species (its taxonomy). If a taxonomist cannot identify the organism, there is now a new way to identify these creatures through their DNA-a tool called DNA barcoding.

\section{What Is DNA Barcoding and How Can We Use It?}

DNA barcoding is an amazing new technique that can help scientists discover and catalog the biodiversity of our oceans. Marine organisms lose cells constantly and these cells are released into the 
Figure 3

Identification of organisms using eDNA barcoding. (1) An environmental sample containing cells and DNA from organisms (eDNA) is blended with a special detergent to release the DNA that is inside the cells. (2) The DNA is extracted (separated from) from the other cellular components using a series of chemicals. (3, 4) The extracted DNA is analyzed (sequenced) for the "barcode" that identifies the species of the organisms. (5) The sequences are compared with online databases, and (6) the species can then be identified $^{1}$

1 Search database icon - Adapted from Search database by Markus, NO. thenounproject.com Animal drawings Courtesy of the Integration and Application Network, University of Maryland Center for Environmental Science (ian.umces. edu/symbols/). Animal drawings courtesy of the Integration and Application Network, University of Maryland Center for Environmental Science.

\section{ENVIRONMENTAL}

\section{DNA (EDNA)}

Genetic material from cells found in an environmental sample, such as seawater, sediments, reefs, or ARMS - that can be used to identify what species were present at a certain time and location.

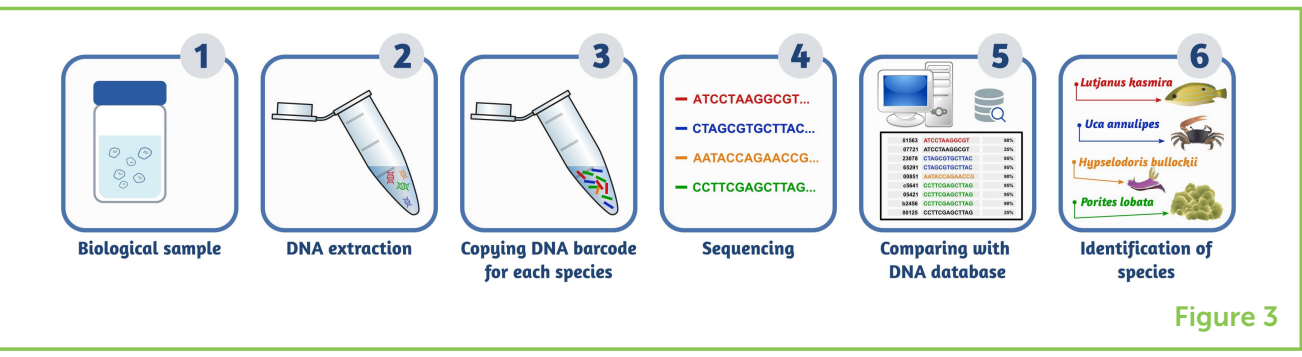

ocean environment. Every individual cell contains the DNA (genetic information) of that species and can be collected from the water, sediment, or ARMS. This genetic information is called environmental DNA, or eDNA, because it is collected from the environment, and eDNA can be used to get an inventory of which species are present at a certain place and time. Each organism's DNA functions as a unique "barcode," like the codes you find on products in the supermarket. The closer two species are, the more similar their DNA is. By examining eDNA, we can find out what species or family the organisms in an environment belong to (Figure 3). These unique DNA codes can be compared to an online database that links that unique code with the name of the species. Sometimes, new species are discovered that are not included in the database. It is estimated that only $86 \%$ of life on Earth has been discovered and recorded-there is still so much we do not know [2].

In the Red Sea, DNA barcoding of eDNA is helping us find sea creatures that no one in the world has described before. As the collection of eDNA expands, researchers can begin to find patterns telling them where the species live and whether species are appearing or disappearing.

\section{UNVEILING THE MYSTERY CREATURES OF THE RED SEA}

Red Sea Research Center scientists have deployed ARMS spanning the Saudi Arabian coast from north to south since 2014. These scientists have found over 10,700 distinct species associated with Red Sea reefs. This is 10 times more than the fish species and 30 times more than the coral species than had previously been identified in the region. Most of the species belong to a group called Arthropoda (such as crabs), followed by fish, mollusks (animals with shells, including snails), and worms (Figure 4). Several species could not be assigned to any known group. Following recovery of the ARMS in the central part of the Red Sea, eDNA barcoding was applied to ARMS deployed at eleven reefs. Scientists found that the groups of organisms identified changed as reefs become more distant from the shoreline toward the center of the Red Sea.

Another thing the scientists learned is that, to conserve and protect species, a marine protected area including a network of protected 
Figure 4

Species found using ARMS in the Red Sea. The $X X$ axis lists the various phyla (groups of related living things that ranks below the kingdom) of the organisms collected, while the $Y Y$ axis shows the number of species. You can see from the graph that most of the species collected belonged to the phylum Arthropoda including the crabs.

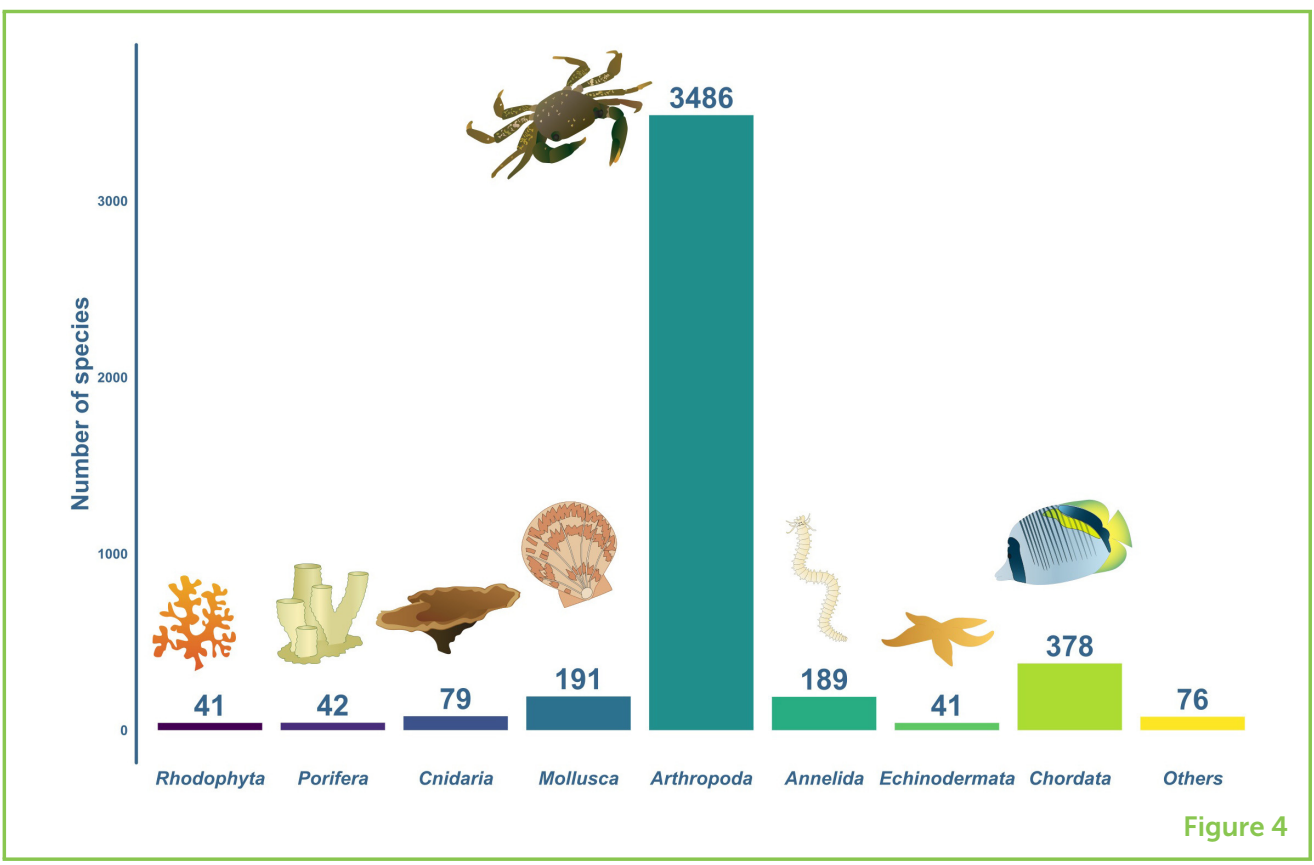

reefs must be established, instead of just protecting the most species-rich reef. This is because some reefs contain species that are very different from those found in another reef, so protecting only one reef will not safeguard the biodiversity of the region.

\section{CAN THE MYSTERY OF THE SEAS BE SOLVED?}

Can we fully know what lies beneath the surface of the seas? Yes and no. Yes, because we now have tools like ARMS and eDNA barcoding that allow for a more rapid and less expensive way of identifying the overwhelming diversity of life in our seas. As these tools evolve and our computer technologies grow, we can expect new and creative methods for identifying marine life. No, because global changes are also causing some of these species to be lost before we can identify them. Also, there are many parts of our seas that are so inaccessible that we cannot use ARMS or collect samples of eDNA in those regions. What we do know is that a biodiverse ecosystem with many different species is more likely to be resilient and to withstand changing conditions. Recording and understanding all marine life inhabiting coral reefs in the Red Sea is one contribution scientists are making to help protect and conserve the planet's marine treasures.

\section{ACKNOWLEDGMENTS}

The authors were grateful to João Curdia for adapting Figure 3, and to the co-authors of the original source articles. Special thanks to the editors Rúben Costa and Christian Voolstra, the reviewers, and the Science mentor (Royale S. Hardenstine) for their thoughtful 
and critical assessment of our article. Their constructive comments and have strengthened this publication. Finally, we would also like to thank Susan Debad for making our article more accessible to a young audience. The research upon which this article is based was supported by the Saudi Aramco-KAUST Center for Marine Environmental Observations.

\section{ORIGINAL SOURCE ARTICLES}

Pearman, J. K., Leray, M., Villalobos, R., Machida, R. J., Berumen, M. L., Knowlton, N., et al. 2018. Cross-shelf investigation of coral reef cryptic benthic organisms reveals diversity patterns of the hidden majority. Sci. Rep. 8:8090. doi: 10.1038/s41598-018-26332-5

Carvalho, S., Aylagas, E., Villalobos, R., Kattan, Y., Berumen, M., and Pearman, J. K. 2019. Beyond the visual: using metabarcoding to characterize the hidden reef cryptobiome. Proc. R. Soc. $B$ 286:20182697. doi: 10.1098/rspb.2018.2697

\section{REFERENCES}

1. NOAA. 2019. Available online at: https://oceanservice.noaa.gov/facts/exploration.html (accessed May 30, 2019).

2. Mora, C., Tittensor, D. P., Adl, S., Simpson, A. G. B., and Worm, B. 2011. How many species are there on earth and in the ocean? PLoS Biol. 9:e1001127. doi: 10.1371/journal.pbio.1001127

SUBMITTED: 15 September 2019; ACCEPTED: 28 January 2020; PUBLISHED ONLINE: 18 March 2020.

EDITED BY: Christian Robert Voolstra, Universität Konstanz, Germany

CITATION: Otoadese J and Carvalho S (2020) Treasure Reef: Revealing the Hidden Creatures of Coral Reefs. Front. Young Minds 8:11. doi: 10.3389/frym.2020.00011

CONFLICT OF INTEREST: The authors declare that the research was conducted in the absence of any commercial or financial relationships that could be construed as a potential conflict of interest.

COPYRIGHT (c) 2020 Otoadese and Carvalho. This is an open-access article distributed under the terms of the Creative Commons Attribution License (CC BY). The use, distribution or reproduction in other forums is permitted, provided the original author(s) and the copyright owner(s) are credited and that the original publication in this journal is cited, in accordance with accepted academic practice. No use, distribution or reproduction is permitted which does not comply with these terms. 

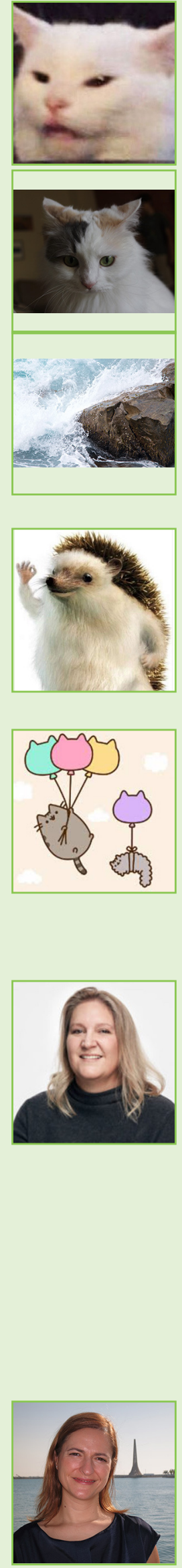

\section{YOUNG REVIEWERS}

\section{BJORN, AGE: 15}

I enjoy 3D modeling and coding, studying, and sports in my free time. I come from Canada, and I believe that making information accessible for all is fundamentally important in preparing for the future.

\section{HAZEM, AGE: 14}

I am Hazem. I am 14. I like to learn things about biology.

\section{REBECCA, AGE: 15}

I am a TCK, and I currently live in an international school in Saudi Arabia. I am half-Canadian and half-Kiwi. I play the violin, rugby (along with various other sports), and love art and gastronomy. I love nature, hiking, and forests.

\section{SAMUEL, AGE: 14}

My name is Samuel and I am from New Zealand. I absolutely love being able to read and understand scientific articles about the latest scientific discoveries. I have lived in Latvia for 2 years and Qatar for 7 years. Trying new things is great and I feel that I should try all the experiences before I am too old to do them.

\section{XENIA, AGE: 15}

My name is Xenia. I like Science and I think it is awesome to be able to read a scientific article and actually understand what it says. In my spare time I like to read, do gymnastics, and take pictures.

\section{AUTHORS}

\section{JENNIFER OTOADESE}

Having lived near the shores of the Arctic, Pacific, Atlantic, and Indian oceans, I am happiest in, on or beside the water. My first snorkeling expedition was in the Red Sea 17 years ago; the beauty of the Sea's diversity was astonishing. I want my children, you, your children to have the same opportunity to behold the splendor of our Blue planet. This is why my career has and will continue to be supporting transformative scientific research and engagement teams to do their best work. I have had the privilege of coordinating marine research, facilitating high-level, cross-sectoral conversations toward 2050 low carbon scenarios, documenting western and indigenous knowledge of climate change in the Arctic, coordinating youth-driven global environmental assessments, and changing policies to protect forests and livelihoods.

\section{SUSANA CARVALHO}

I am a marine ecologist passionate about understanding and protecting marine biodiversity. Living in Saudi Arabia since 2012, I have been working at the King Abdullah University of Science and Technology. I investigate how biodiversity and functioning of the Red Sea ecosystems change as a result of human or 
natural disturbances. I have been particularity involved in studies incorporating DNA-based tools in aquatic biomonitoring and biodiversity projects from microbes to fish. I am also very interested on how biological diversity is distributed around the world. *susana.carvalho@kaust.edu.sa 